May 22nd, 2:45 PM

\title{
The Telephone Consumer Protection Act of 1991
}

Danielle Waltz Esq.

Jackson Kelly

Follow this and additional works at: https://researchrepository.wvu.edu/ccle-events

Part of the Consumer Protection Law Commons

\section{Recommended Citation}

Waltz, Danielle Esq., "The Telephone Consumer Protection Act of 1991" (2019). Center for Consumer Law and Education Events. 18. https://researchrepository.wvu.edu/ccle-events/CLE/ConsumerLaw2020/18

This Event is brought to you for free and open access by the The Center for Consumer Law and Education at The Research Repository @ WVU. It has been accepted for inclusion in Center for Consumer Law and Education Events by an authorized administrator of The Research Repository @ WVU.

For more information, please contact ian.harmon@mail.wvu.edu. 
The Telephone Consumer Protection Act of 1991

\title{
Danielle Waltz, Esquire
}

\author{
Jackson Kelly
}


West Virginia Continuing Legal Education is sponsored by the West Virginia University College of Law. WVCLE does not render any legal, accounting, or other professional services. Its programs and publications are designed solely to help attorneys maintain their professional competence. The attorney using WVCLE publications or orally conveyed information in dealing with specific legal matters should also research original sources of authority. In no event will the authors or the publisher be liable for any direct, indirect or consequential damages resulting from the use of this material.

Copyright $\odot 2019$

West Virginia Continuing Legal Education

All Rights Reserved 


\section{The Telephone Consumer Protection Act of 1991}

DANIELLE WALTZ, JACKSON KELLY

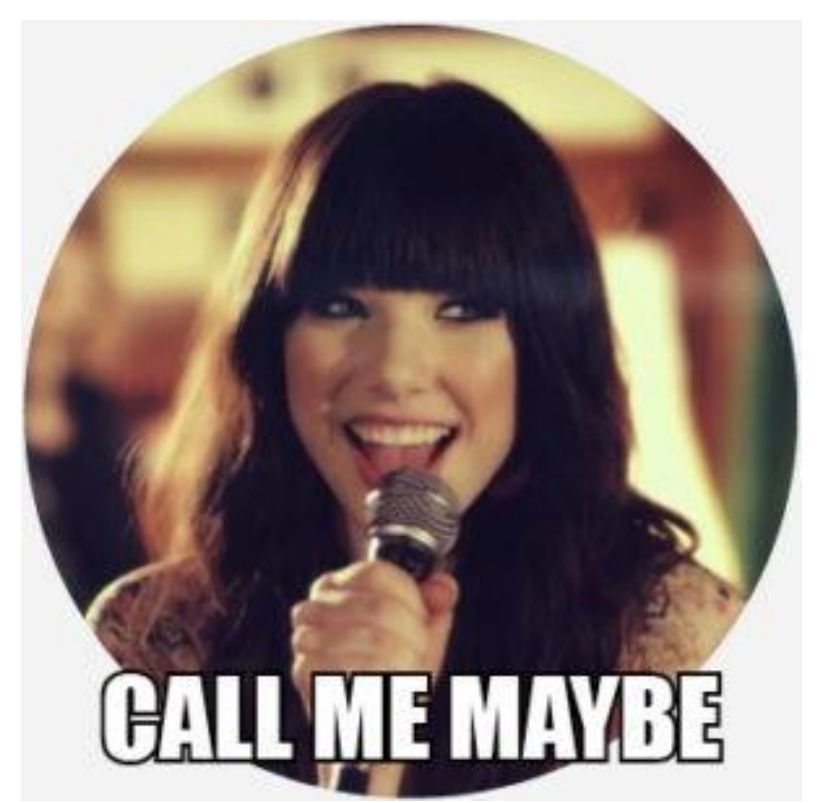




\section{What is the Telephone Consumer Protection Act?}

The Telephone Consumer Protection Act or TCPA of 1991, 47 U.S.C. § 227, "generally prohibits the use of certain kinds of automated dialing equipment to call wireless telephone numbers absent advance consent." ACA International v. FCC, 885 F.3d 687, 691 (D.C. Cir. 2018).

TCPA is overseen by the Federal Communications Commission (FCC). See 47 U.S.C. § 227(c).

\section{What is the Telephone Consumer Protection Act? (continued)}

More specifically, according to the Southern District of West Virginia, the TCPA creates a remedy for:

1. Automatic Telephone Dialing System (or an ATDS) calling a "cellular telephone or other service for which the receiver is charged for the call"

2. "Using artificial or prerecorded voice messages to call residential telephone lines without prior consent."

3. "Unsolicited advertisements to fax machines."

4. Automatic Telephone Dialing System from engaging "two or more of a business' telephone lines simultaneously." 


\section{Who can sue?}

The Attorney General may "[b]ring an action on [behalf] of state residents [if he] has reason to believe that any person has engage....in a pattern or practice" of violating the TPCA. 47 U.S.C. § $227(g)(2)$.

A harmed person has a "[p]rivate right of action." See 47 U.S.C. § 227(b)(3).

\section{Exception for Consenting Parties}

TCPA allows an ATDS (Automatic Telephone Dialing System) to contact a consenting party. See 47 U.S.C. § $227(b)(1)(A)$.

AND...

No liability would attach if "the number [autodialed] in fact has been reassigned to another person who has not consented." ACA International v. FCC, 885 F.3d 687, 693 (D.C. Cir. 2018).

BUT...

"[A] consenting party can revoke her consent to receive autodialer calls... whether orally or in writing - 'that clearly expresses a desire not to receive further messages.'" ACA International v. FCC, 885 F.3d 687, 693 (D.C. Cir. 2018)(citing 2015 Declaratory Ruling, 30 FCC Rcd. At 7996 ๆ 63). 


\section{Who has jurisdiction over a TCPA claim?}

State courts and federal courts. Mims v. Arrow Financial Services, LLC, 132 S.CT. 740, 745 (2012).

The Court reasoned that "[b]ecause federal law creates the right of action and provides the rules of decisions, Mims's TCPA claim, in 28 U.S.C. 1331's words, plainly 'aris[es] under' the laws...of the United States.” Mims v. Arrow Financial Services, LLC, 132 S.CT. 740, 744 (2012).

\section{What about Article III Standing?}

In 2016, the Northern District of West Virginia granted a stay in Mey v. Got Warranty, a case involving a TCPA claim, in light of the pending Spokeo decision.

After the Spokeo decision was handed down, the Northern District ruled that "unwanted phone calls cause concrete harm...by depleting limited minutes that the consumer has paid for or by causing the consumer to incur charges for calls. In addition, all ATDS calls deplete a cell phone's battery, and the cost of electricity to recharge the phone is also a tangible harm. While certainly small, the cost is real, and the cumulative effect could be consequential." Mey v. Got Warranty, 193 F.Supp.3d 641, 645 (N.D.W. Va. 2016). 


\section{Open Questions}

\section{What is an Automatic Telephone Dialing System?}

According to the statute, an ATDS is:

"equipment which has the capacity...to store or produce telephone numbers to be called, using a random or sequential number generator... and [which has the capacity] to dial such numbers." 47 U.S.C. § $227(\mathrm{a})(1)(\mathrm{A}),(\mathrm{B})$.

According to the Northern District of West Virginia, an ATDS is:

equipment that "makes calls from a stored list of phone numbers without human intervention." Moore v. Dish Network L.L.C., 47 F.Supp.3d 639, 655 (N.D.W. Va. 2014).

According to a 2015 declaratory ruling by the FCC (overruled by District of Columbia Court of Appeals in ACA international) an ATDS is:

Defined by its "potential functionalities" and not its "present capacity." 2015 Declaractory Ruling, 30 FCC Rcd. At 7974 ๆ 16. But the FCC failed to "clarify that a dialer is not an autodialer unless it has the capacity to dial numbers without human intervention." 2015 Declaractory Ruling, 30 FCC Rcd. At 7976 ๆ 20. 


\section{Potential Impact}

Why is this a big deal? Because a broad definition of ATDS "could potentially sweep in smartphones because they may have the capacity to store telephone numbers to be called and to dial such numbers through the use of an app or other software." ACA International v. FCC, 885 F.3d 687, 697 (D.C. Cir. 2018)(citing 2015 Declaratory Ruling, 30 FCC Rcd. at 7976 ๆ 21).

According to a Pew Research Center study, "nearly $80 \%$ of American adults [are] smartphone owners." See 10 Facts About Smartphones *698 as the iPhone Turns 10, Pew Research Ctr., June 28, 2017, http://www.pewresearch.org/fact-tank/2017/06/28/10-facts-about-smartphones (last visited Dec. 18, 2017).

\section{How to calculate damages?}

Up to $\$ 500$ for "each such violation." See 47 U.S.C. § 227(G)(3)(B).

Does "each such violation" modify "telephone call within any 12-month period," meaning that damages are calculated per call or modify "in violation of the regulations," meaning that more than one violation can occur per call (measured by amount of rings per call)?

Answer, per call. See Charvat v. GVN Michigan, 531 F.Supp.2d 922, 927 (S.D. Ohio 2008).

But federal courts in West Virginia and the $4^{\text {th }}$ Circuit have not addressed this issue. 


\section{Agency Law}

In order to prove vicarious liability, a plaintiff must show that the defendant "controlled or had the right to control [the alleged agent] and, more specifically, the manner and means of the solicitation campaign that was conducted." Mey v. Pinnacle Security, LLC, 2012 WL 4009718 at *5 (N.D.W. Va. 2013)(holding that the plaintiff did not adequately show defendant's "ability to control the manner and means of the calls made on its behalf.")

But...

"[A]ssisting a party in setting up telemarketing centers or providing scripts for in-person calls is not evidence of agency." In re: Monitronics International, Inc., Telephone Consumer Protection Act Litigation, 223 F.Supp.3d 514, 521 (N.D.W. Va. 2016). 